\title{
URBAN HEAT ISLAND (UHI) SIMULATIONS IN THE NORTH REGION OF PARANA STATE, BRAZIL
}

\author{
Veronika S. Brand ${ }^{1, *}$, Carolyne B. Machado ${ }^{1}$, Maurício N. Capucim ${ }^{1}$, Leila D. Martins ${ }^{1}$, Jorge A. \\ Martins ${ }^{1}$, Camila T. Homann ${ }^{3}$ \\ ${ }^{1}$ Universidade Tecnológica Federal do Paraná - Londrina (PR) \\ ${ }^{3}$ Instituto de Astronomia, Geofísica e Ciências Atmosféricas - São Paulo (SP) \\ *vsbrand@eaelab.org
}

\begin{abstract}
This work aims to study an urban heat island (UHI) in the North region of Parana State and the influences of land use on the intensity and frequency of occurrence of these events, including especially urban environments. Two simulations were conducted with WRF/Chem model with different land use files (original file and Landsat database). The simulations represented well the observed data with correlation above 0.92 for Londrina region. The simulation with the land use Landsat represented better the UHI and the temperature gradient was well demonstrated. The model underestimated the maximum and overestimated minimum temperatures compared to the observed data in the two simulations.
\end{abstract}

\section{RESUMO}

Este trabalho teve como objetivo estudar a ilha de calor urbana (ICU) na região Norte do Paraná e a influência do uso do solo, incluindo especialmente ambientes urbanos, na intensidade e frequência de ocorrência desses eventos. Duas simulações foram feitas com o modelo WRF/Chem com diferentes arquivos de uso do solo (arquivo original e da base de dados do Landsat). As simulações representaram bem os dados observados com correlações superiores a 0,92 para a região de Londrina. A simulação com o uso do solo do Landsat representou melhor as ilhas de calor urbanas (ICU) e o gradiente de temperatura foi bem evidenciado. O modelo subestimou os valores máximos e superestimou os mínimos comparando com os dados observados nas duas simulações.

\section{INTRODUCTION}

The fast and disorganized growth of urban settlements modified the land use pattern. The high demographic concentration and its associated activities provoke impacts that reach areas beyond city boundaries like heat islands. 
The urban heat island (UHI) is characterized by the temperature contrast between the central and the peripheral regions. Urbanization quickly increases and slowly decreases the temperature. Thus, more densely populated areas with less wooded spaces tend to have higher temperatures, even at night.

This work aims to study the heat island on North region of Parana state, Brazil through atmospheric modelling and also to understand the possible influences of land use and urban settlements in the magnitude and frequency of occurrence of these events that can affect energy demand and dispersion of pollutants.

\section{METHODOLOGY}

Two simulations were conducted with different land use files:

1) original land use of WRF/Chem, USGS (1993) (WRF Land Use);

2) land use change obtained from a composition of MODIS vegetation file with the replacement of urban class from the classification of a LANDSAT 5 image of 9/11/2011 (Landsat Land Use).

For this, we used the Weather Research and Forecasting/Chemistry model (WRF/Chem) version 3.2.1. The WRF/Chem is a fully coupled model, where the meteorological and chemical processes are integrated (Grell et al., 2005).

The period of simulation was 7 July through 16 July 2011. A simulation region was centered in the coordinates $-23.31^{\circ}$ and $-51.16^{\circ}$ with 3 squared nested grids of 82,64 and 64 points, 9,3 and $1 \mathrm{~km}$ of resolution and 28 vertical levels.

The results generated by the third grid were compared with observed data of the ICALON experiment that measured the air temperature of 13 sites (Coraiola et al., 2012). The comparison was made per statistical tests to verify the ability of the model to represent the actual atmospheric variables. Some of the tests used were Pearson linear correlation coefficient $\left(\mathrm{R}_{\mathrm{xy}}\right)$, mean error $(\mathrm{ME})$, mean squared error (MSE), root mean squared error (RMSE) and root mean squared error UB (RMSEUB), defined by Pielke (2002). According to Pielke (2002), the skill of the simulation can be evaluated as to:
1) $\sigma_{\mathrm{sim}} \cong \sigma_{\mathrm{obs}}$
2) $\mathrm{RMSE}<\sigma_{\mathrm{obs}}$;
3) $\operatorname{RMSE}_{U \mathrm{~B}}<\sigma_{\text {obs. }}$

\section{RESULTS}


Comparing the two Land Use files used on the simulations (Figure 1), the original file (a) was very homogeneous and couldn't represent the real complexity of the mix of land uses. The urban areas (class 1) were underestimated and little cities didn’t even appear. Besides, the predominant vegetation was Savanna (class 10) and in this region it is known that there are predominantly croplands and mixed shrubland/grassland (classes 5, 6 and 9) and some isolated forests as we can see in (b).

Urban areas presented higher temperatures than its surroundings (Figure 2-a,b) and Landsat land use have simulated higher temperatures than WRF land use (Figure 2-c). The simulation performed with a new land use representation was able to represent better the UHI observed in that period (Figure 2-b), which presented favourable conditions to the development of heat islands.

The UHI was more developed during the night, probably because of the stability of the atmospheric boundary layer during night with less convective air circulation concentrating pollutants over cities and increasing the concern with public health and air quality.

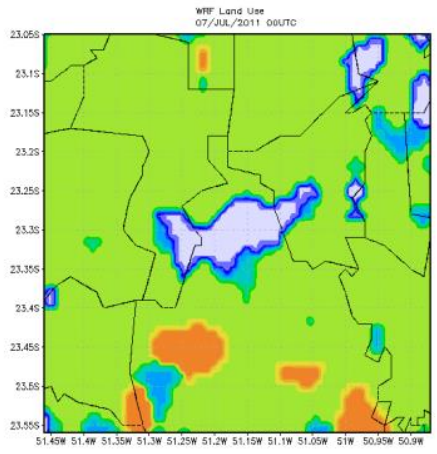

(a)

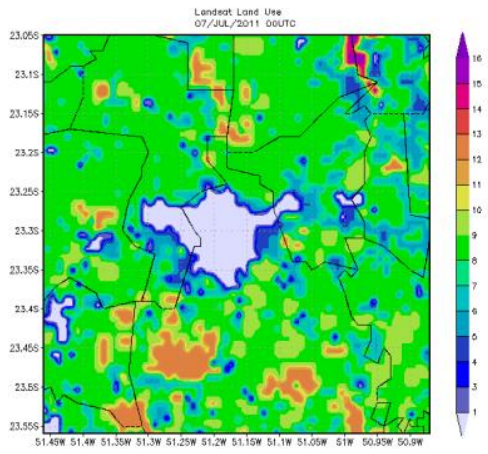

(b)

Figure 1 - Land Use representation of (a) WRF model and (b) composition of Landsat.

According to the tests applied in the temporal series, the Landsat Land Use simulation showed a good skill. Analyzing the results, in general, the correlation coefficient $\left(\mathrm{R}_{\mathrm{xy}}\right)$ showed similar and high values, varying from 0.92 to 0.98 . By mean squared error analysis (MSE), it can be noticed that the model underestimated $(\mathrm{MSE}<0)$ temperatures values.

The model in general underestimated the maximum values and overestimated the minimum values compared with observed data, although, the simulation presented a good skill. On the temporal variation profile of air temperature, it can be observed a good correlation between simulated and real data. 


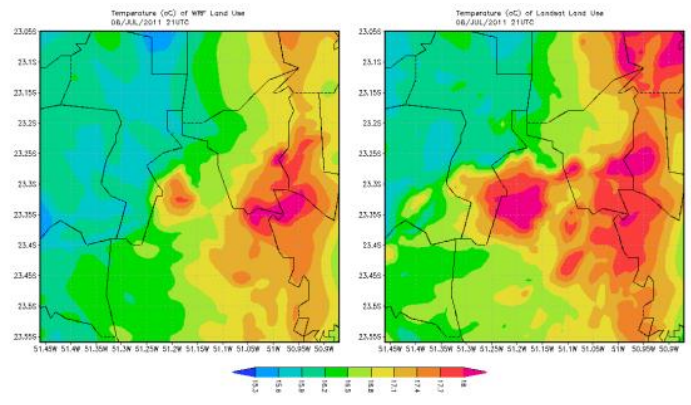

(a) (b)

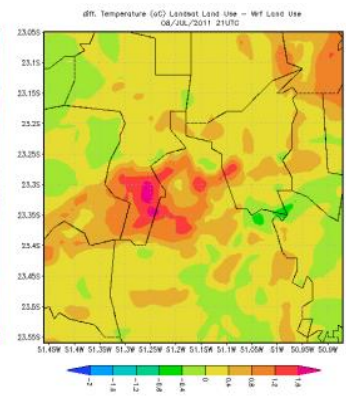

(c)

Figure 2 - (a) WRF and (b) Landsat Land Use simulated temperature $\left({ }^{\circ} \mathrm{C}\right.$ ), (c) Difference between Landsat and WRF Land Use simulated temperature $\left({ }^{\circ} \mathrm{C}\right)-08 / 07 / 2011-21$ UTC.

\section{CONCLUSION}

An adequate land use representation is important to represent UHI and consequently to calculate pollutants concentration on air quality simulations. The model was able to simulate the $\mathrm{UHI}$ and presented a good skill to simulate temperature. Thus, regionalization and calibration is essential for reliable results. Landsat land use represented better UHI and the gradient between urban and rural areas was well demonstrated. Better results of the simulations could be made with the increase of the model resolution and the coupling with urban models.

\section{ACKNOWLEDGEMENTS}

The authors acknowledge the National Counsel of Technological and Scientific Development (CNPq), Araucária Foundation, Federal Technological University of Parana.

\section{REFERENCES}

Coraiola, G. C.; Targino, A. C.; Krecl, P. (2012). Desenvolvimento espaço-temporal da intensidade da Ilha de Calor Urbana em Londrina durante o inverno. In: XVII Congresso Brasileiro de Meteorologia, Gramado, Brazil.

Grell, G. A.; Peckham, S. E.; Schmitz, R.; Mckeen, S. A.; Frost, G.; Skamorock, W. C.; Eder, B. (2005). Fully coupled "online" chemistry within the WRF model. Atmospheric Environment 39, 6957-6975.

Pielke, R.A. (2002). Mesoscale meteorological modeling. Second Edition. International Geophysics Series, vol 78. Academic Press. 